\title{
Conceptualizing Couples' Decision Making in PGD: Emerging Cognitive, Emotional, and Moral Dimensions
}

\author{
Patricia E. Hershberger, Ph.D., A.P.R.N., B.C. ${ }^{a}$ and Penny F. Pierce, Ph.D., R.N., F.A.A.N. ${ }^{b}$ \\ a University of Illinois at Chicago, College of Nursing and College of Medicine, Chicago, IL 60612 \\ b University of Michigan, School of Nursing and Institute for Social Research, Ann Arbor, MI \\ 48109
}

\section{Abstract}

Objective-To illuminate and synthesize what is known about the underlying decision making processes surrounding couples' preimplantation genetic diagnosis (PGD) use or disuse and to formulate an initial conceptual framework that can guide future research and practice.

\begin{abstract}
Methods-This systematic review targeted empirical studies published in English from 1990 to 2008 that examined the decision making process of couples or individual partners that had used, were eligible for, or had contemplated PGD. Sixteen studies met the eligibility requirements. To provide a more comprehensive review, empirical studies that examined healthcare professionals' perceptions of couples' decision making surrounding PGD use and key publications from a variety of disciplines supplemented the analysis.
\end{abstract}

Results-The conceptual framework formulated from the review demonstrates that couples' PGD decision making is composed of three iterative and dynamic dimensions: cognitive appraisals, emotional responses, and moral judgments.

Conclusion-Couples think critically about uncertain and probabilistic information, grapple with conflicting emotions and incorporate moral perspectives into their decision making about whether or not to use PGD.

Practice Implications-The quality of care and decisional support for couples who are contemplating PGD use can be improved by incorporating focused questions and discussion from each of the dimensions into counseling sessions.

\section{Introduction}

In 1990, groundbreaking reports surfaced from London [1] and Chicago [2] that outlined the procedures for diagnosing genetic disorders in human embryos or oocytes in vitro. The London scientists also reported healthy pregnancies following their procedures, now known as Preimplantation Genetic Diagnosis or PGD, making this novel approach a valid option. In the next twelve years, about 1000 babies were born using PGD [3-4]. In recent years, the use of PGD sharply increased; over 600 babies were born worldwide in a one-year period alone [5].

Reprint requests: Patricia E. Hershberger, Ph.D., A.P.R.N., B.C., University of Illinois at Chicago, College of Nursing and College of Medicine, 845 S. Damen Ave. (MC 802), Chicago, IL 60612 (FAX: 312-996-8871; phersh@uic.edu).

Publisher's Disclaimer: This is a PDF file of an unedited manuscript that has been accepted for publication. As a service to our customers we are providing this early version of the manuscript. The manuscript will undergo copyediting, typesetting, and review of the resulting proof before it is published in its final citable form. Please note that during the production process errors may be discovered which could affect the content, and all legal disclaimers that apply to the journal pertain. 
As the knowledge and techniques of molecular genetics continue to evolve, so does the use and applications for PGD. In 1992, PGD was introduced as a way to identify single gene disorders [6]. PGD is now used to test embryos for more than 50 genetic conditions [5]. This number may be much higher as several predominant private laboratories have reported testing embryos for more than 150 genetic conditions on their Internet web sites [7-8]. Other applications for PGD include the selection of embryos according to their human leukocyte antigen (HLA) type in order to treat an ill sibling [9] and identifying sex chromosomes for non-medical sex selection. The number of requests for PGD for different genetic applications continues to grow, driving a need for highly technical skills and reliable procedures for any given genetic disorder [10-13]. Recently, there has been a trend towards using PGD for adult-onset inherited predispositions [14-15] including Alzheimer disease [16] and familial adenomatous polyposis coli [17], foreshadowing the potential expansion of PGD to other applications.

As the applications for PGD expanded, it developed an application for screening purposes, currently referred to as preimplantation genetic screening. In this instance, embryos are assessed for chromosome aneuploidies (i.e. too many or too few chromosomes) to enhance the chance of establishing an ongoing pregnancy. While initially thought to improve the pregnancy success rate, current research has challenged the benefit of preimplantation genetic screening [18-19], prompting some professional organizations to recommend against preimplantation genetic screening for women with advanced maternal age, previous implantation failure, or recurrent pregnancy loss [20].

Since the inception of PGD, there has been a call for research that addresses the impact of this new and rapidly developing technology that alters the basic human elements of reproduction and genetics. Scholars from a variety of disciplines suggest that it is essential to understand how the merging of genetic and reproductive advances affect the lives of individuals, couples, families and society [21-23]. Moreover, specific efforts aimed at understanding the decision making process facing couples contemplating this burgeoning technology will be beneficial to both scientists and clinicians as they attempt to understand and provide accurate and relevant information as well as decisional support [24-27].

Understanding couples' decision making surrounding the use of PGD is supported by professional practice groups that have developed guidelines recommending adequate patient counseling and informed consent for PGD [20,28-29]. Decision making surrounding PGD also provides an important real world opportunity for understanding naturalistic decision making among couples [30] since PGD is inherently dependent upon both male (sperm) and female (oocyte) gamete contributions. Furthermore, leaders in medical decision making have strongly encouraged investigators to undertake the long, tedious, and often difficult task of understanding decision making as it occurs in natural settings to acquire conceptual knowledge [30]. Therefore, the purpose of this review of published scientific and bioethical literature is to illuminate and synthesize what is known about the underlying decision making processes surrounding couples' PGD use or disuse and to formulate a conceptual framework derived from the literature that identifies the essential dimensions of couples' decision making.

\section{Methods}

This systematic review targeted empirical studies published in English from 1990 to 2008 that examined aspects of the decision making process of couples or individual partners that had used, were eligible for, or had contemplated PGD. Several search strategies were used to identify relevant literature including computerized searches of electronic databases (i.e. ERIC, ISI Web of Knowledge, PsycINFO, PubMed), ancestry approaches, and citation 
index searching [31]. Sixteen published research reports were identified for inclusion (see Table 1).

Due to the limited number of empirical studies identified that met the eligibility requirements, the search was expanded to include (1) empirical studies published in English that examined healthcare professionals' perceptions of couples who were contemplating or undergoing PGD, and (2) key publications that addressed aspects of the PGD decision making process. The latter consisted of commentaries, professional guidelines, policy reports and other reviews published in English and represent a collective voice of distinguished and emerging scholars from anthropology, bioethics, law, medicine, social sciences, and women's studies. The three-tiered inclusion approach, with the sixteen empirical studies guiding the analysis, allowed the focus to remain on couples' decision making surrounding PGD use yet provided more depth and completeness to the review and emerging framework. The exclusion of non-English publications was necessary as neither author is multilingual and budgetary constraints prevented the use of a professional translator.

After the empirical studies and key publications were identified, an interpretive synthesis [48] guided the analysis to meet the aims of the project. The sixteen empirical studies were read in their entirety and then re-read with a distinct focus of identifying aspects or indicators of the couples' underlying decision making processes. Although the sixteen empirical studies did not examine decision making processes explicitly, aspects or indicators that provided evidence of the underlying decision making processes of couples or individual partners in the published text were identified as raw data and coded. This substantive coding approach has been articulated by Glaser [49] and Glaser and Strauss [50]. The particular code was a term that best described the raw data. During the initial coding and throughout the analysis, we were astute to the evolution and trajectory of PGD, whereas PGD subjects in the early studies were often combined with subjects contemplating or undergoing preimplantation genetic screening. When possible, we would tease out the two subject groups and did not include coded data in the analysis that could be linked to the preimplantation genetic screening group.

As the process of coding the sixteen empirical studies continued, we began to identify codes that could be grouped into sub-categories that reflected the meaning in the data. Concurrently, we read and re-read all of the healthcare professional studies and key publications. It should be noted that data derived from the sixteen empirical studies identified in Table 1 led the analysis so that all emerging sub-categories were directly related to one or more codes from these empirical studies. The healthcare professional studies and key publications provided context, understanding, and hence more depth and complexity to what could otherwise be synthesized from the sixteen empirical studies themselves. The identified sub-categories were integrated and emerged into the three dimensions of couples' decision making thereby grounding these data to the conceptual framework.

As described, this process may appear linear. Yet it was often iterative as is typical for an interpretative synthesis that seeks to combine the findings from several studies into a whole that provides a new conceptual development [48]. Furthermore, in developing the conceptual framework, there were instances of creative and inventive processes that occurred while immersed with these data and identifying conceptual relationships. We acknowledge these cognitive processes that were first articulated in detail by philosopher Carl Hempel [51], who sought to understand conceptual and theoretical development among investigators. 


\section{Results}

Three critical dimensions of PGD decision making emerged from our review: (1) cognitive appraisals, (2) emotional responses, and (3) moral judgments. Figure 1 depicts this conceptual framework. In this article, each dimension is described separately; however, we caution that the dimensions are not mutually exclusive and fixed but rather are iterative and dynamic. We also acknowledge there may exist other factors involved in decision making beyond the scope of this review, such as couples' interpersonal communication with providers (e.g. framing effects) and between themselves [52-53]. A discussion of these factors is beyond the scope of this initial paper that aims to describe the underlying decision making processes of couples who were eligible for PGD, in the process of contemplating PGD, or had used PGD.

\subsection{Cognitive appraisals}

The PGD decision making process is cognitively demanding and complex. Couples are often presented with a vast amount of information about success rates, procedures, and short- and long-term health risks. Additionally, couples must appraise financial costs and the amount of time necessary to complete the PGD procedure. Adding to the complexity of the decision, PGD requires in vitro fertilization (IVF) to allow access to developing embryos. Furthermore, intracytoplasmic sperm injection is often performed in addition to IVF to provide a clear sample of the nuclear material and optimize the genetic analysis [54].

3.1.1. Success rates-Currently, the overall success rates for IVF when PGD is used fall below the general live birth rates for IVF alone (see Box 1). For example, the overall IVF success rates in the United States for fresh non-donor cycles that result in pregnancy is about $35 \%$ and the rate for a live birth is about 29\% [56]. In contrast, the pregnancy rate for IVF with PGD is lower (19\%), according to the ESHRE PGD consortium [5] although trending upward. This consortium consists of 39 centers that include but are not limited to centers in Europe, Argentina, Australia, Brazil, Israel, Korea, Taiwan and the United States that complete IVF with PGD and therefore provides a worldwide picture of IVF with PGD success rates [5]. If data are available, couples may also appraise IVF with PGD success rates from specific centers, some of which have reported higher birth rates than the current worldwide consortium data [15,57].

\section{Box 1}

\section{Success Rates in Assisted Reproductive Technology}

Assisted Reproductive Technology success rates and hence PGD success rates are reported in a variety of descriptive ways (e.g. oocyte retrieval clinical pregnancy rate, oocyte retrieval live birth rate, embryo transfer clinical pregnancy rate, embryo transfer live birth rate). There is a growing call for standardization to enhance understanding in the field. Additionally, success itself can be interpreted in various ways. For many investigators and clinicians, success is often understood as a noted positive heart rate of a developing fetus where as others consider only the birth of a singleton healthy child a success. For further discussion, see Soini [25] and Min [55].

Success rates can also vary depending on the specific application of PGD. Higher success rates are observed when PGD is used to identify chromosomal abnormalities (23\% implantation rate) compared to non-medical sex selection (19\% implantation rate) [5]. Patient history is also a factor when appraising PGD success rates. Couples who had previously undergone PGD or who were at high risk for transmitting a genetic disorder have reported that the low success rate of PGD was a main deterrent for its use $[32,41]$. 
3.1.2. Procedural risks-Couples who undergo PGD are faced with the potential for embryo misdiagnosis or undiagnosis resulting from the PGD analysis procedure. In the case of misdiagnosis, an affected embryo believed to be normal is transferred to the uterus. Alternatively, a normal embryo believed to be affected is discarded. In the case of undiagnosis, there is an inability to determine whether or not the embryo is normal or affected. Although the potential for misdiagnosis is relatively low overall, the risk of misdiagnosis for single gene disorders is estimated at about $2 \%$ for recessive disorders and about $11 \%$ for dominant disorders [58]. Work aimed at refining the precision of the genetic analysis is ongoing [12,59].

The ability of couples to evaluate procedural and probabilistic risk information can be difficult yet little is known about how couples process the information and assess risk in this context. Even when providers assist patients in understanding information and risk, misinterpretation and selective listening can occur. In one empirical study, a woman recounted her PGD experience and openly acknowledged that she received counseling about undiagnosed risks but stated that the information, "didn't hit home" [44].

3.1.3. Human risks and safety-Since PGD is used in conjunction with IVF, informed couples need to cognitively assess and appraise the risks of IVF as well. The IVF procedure can lead to multiple gestation and the associated risk of preterm birth. Prospective PGD users should consider these risks, as multiple gestation can put the family at financial risk and prematurity can adversely affect the health of the pregnant woman and developing child [60]. Indeed, Snowdon and Green [35] found that a majority of men (79\%), who are carriers of recessive disorders, indicated that risk to their partner's health was an important disadvantage to using PGD. Women in the same study, however, viewed health risks to themselves or their partner as much less of a deterrent to using PGD. With regard to weighing health risks, it is important to note that not all couples view health risks equally. In a survey of 36 couples who had undergone 76 PGD cycles, $96 \%$ of couples voiced a potential advantage of PGD use was the increased possibility of undergoing a multiple pregnancy and having twins [41].

Adding to the concerns of immediate health risks of PGD in pregnancy and birth, there is uncertainty about the long-term consequences of PGD. Most notably, studies examining the outcomes of children following PGD are ongoing and conclusive results are not yet available. What is presently known is that babies born following PGD appear to be healthy $[15,61]$ and the prevalence of birth defects does not differ from the reported population prevalence [62]. However, an accurate assessment of the long-term consequences of children conceived using PGD is complicated, as it is used in conjunction with other procedures including IVF and intracytoplasmic sperm injection.

Present knowledge of children conceived via IVF is accumulating worldwide and most reports indicate the incidence of childhood abnormalities is low and children do appear to develop normally [60]. However, some reports have aroused concern and there is a need for prospective longitudinal multicenter studies both nationally and internationally [60,63-64]. What may be of particular concern to potential PGD users is the question of a possible link to IVF use and an increase in genetic birth defects such as Beckwith-Wiedemann [65]. The potential for genetic birth defects may be especially perplexing to couples considering PGD as they are often trying to prevent a genetic disorder in their offspring. The lack of conclusive data about the health of IVF conceived children, albeit among studies using small sample sizes, contributes to the uncertainty and complexity of PGD decision making. What is known is that among couples who have used PGD there are expressed concerns about risks and safety including what the long-term effects on their PGD conceived children might be [44]. 
3.1.4. Financial costs-For many couples, the financial cost and insurance coverage of PGD can greatly influence their decision on whether or not to use PGD [32,41]. Worldwide, the cost of IVF alone is clearly prohibitive to many people [66-70]. In the United States for example, the cost for IVF ranges from $\$ 10,000$ to $\$ 14,000$ US dollars per IVF cycle and often more than one cycle is needed to achieve pregnancy [71,72]. PGD adds an additional cost of $\$ 2,500$ to $\$ 5,000$ US dollars per cycle [71]. Adding evidence to the significance of the financial cost as a consideration in couple's decision making is that in nations with national health insurance where there is IVF coverage, higher rates of couples seeking treatment are reported than couples in the United States where no national system for insurance is in place [73,74]. Additionally, when an individual state within the United States mandates health insurance for IVF, overall rates for utilization typically rise $[75,76]$. For many couples who must incur the financial cost of both PGD and IVF, this can be an insurmountable barrier that can completely determine whether or not the couple will use PGD [77-78].

3.1.5. Time-Another factor in PGD decision making is couples' appraisal of time. The pressure to establish pregnancy within a short period of time, the age of the individuals in the couple and the time needed to organize, schedule and attend office visits with physicians, education sessions with nurses, counseling sessions with geneticists and psychologists, and the time required to undergoing hormonal stimulation, can influence the couple's decision [79]. Women, in particular, may view the lengthy period of time to undergo and complete PGD as problematic [35]. Furthermore, in some cases, couples may also consider that their agreement to proceed with PGD will affect the timing of when they can pursue adoption [43].

\subsection{Emotional responses}

Emotion is an important dimension affecting PGD decision making. Although few of the empirical reports examined this dimension, couples or individual partners have reported that their responses to actual or potential sensations of pain, suffering, joy, and happiness have significantly shaped their decision making.

3.2.1. Pain and suffering-According to reports of potential and actual PGD users, the primary reason for undergoing PGD is to avoid or reduce the probability of future pain and suffering by the couple and their offspring $[32,35,39,41,43]$. Couples who are raising a chronically or terminally ill child have openly described the suffering their children experience and the tremendous emotional stress this places on their family [44]. As one couple reflecting on their use of PGD reported, “... we see it [PGD] as something that can... prevent children dying, basically, that's why we're using PGD" [43]. The desire to alleviate pain and suffering is more pronounced among families who use PGD to have a HLA matched offspring to save a dying child [44]. With the advent of PGD for adult onset genetic disorders such as breast and ovarian cancers, women with the BRCA gene mutations have also expressed a desire for diminishing the emotional trauma among their future offspring who would be free of the mutations via PGD [47].

Other emotions that influence PGD decision making include a desire to avoid or minimize regret, guilt, shame, sadness, and despair. Investigators from two separate studies have indicated that previous experience of pregnancy termination for a genetic disorder is influential in accepting PGD for some couples and, in particular, women [34,36]. Yet, there is no clear consensus among couples at high risk for transmitting a genetic disorder that the decision to use PGD is overwhelmingly influenced by a desire to avoid the emotional trauma related to a pregnancy termination $[35,38]$. 
3.2.2. Joy and happiness-Couples considering PGD have expressed expectations of optimizing the joy and happiness of raising a healthy child of their own and experiencing parenthood during the raising of one's own prodigy. Studies supporting the influence of these positive emotional responses include Kalfoglou and colleagues [44] and in particular Snowdon and Green [35] who found that $85 \%$ of childbearing age couples who were known carriers of a recessive genetic disorder acknowledged that having a genetic link to the child was an important consideration to using PGD. Similarly, studies of couples who use IVF [80] and donor oocytes [81] have demonstrated the extent to which couples may go to establish a genetic connection with their child. Not many investigators have addressed the emotional responses as a dimension of the decision making process; however, the magnitude of the impact that emotions play on decision making in this context may be significant.

Research incorporating emotions into the decision making process is in the early stages, not only in PGD but in other decision making contexts [82].

\subsection{Moral judgments}

While PGD decision making is heavily influenced by cognitive appraisals and emotional responses, several of the sixteen empirical studies and a substantial amount of literature has focused on moral judgments. Although none of the sixteen empirical studies set out to explicitly examine how couples weigh the moral implications in their own decision making, moral judgments were imbued within aspects of the decision making process uncovered among the sixteen studies. These judgments comprise the third underlying dimension of decision making and center on the couple's moral evaluations related to the status of the embryo, the technological imperative, disability and disease prevention, social significance, and the underlying application for PGD.

3.3.1. Status of the embryo-The decision to use PGD is often guided by the couple's judgment and understanding of the moral status of the embryo [77,83-86]. In general, the moral status of the embryo includes the couple's personal assessment of the embryo's genetic uniqueness, its potential for full and healthy development, sentience, brain activity, level of cognitive development, human physical form, capacity for survival outside the uterus, and its ability to establish relationships with other persons $[87,88]$.

Determining an embryo's status and its potential looms large for PGD users since by design, PGD selects embryos for immediate implantation or cryopreservation (i.e. freezing for the future) and typically disposes of other embryos. Although cryopreservation is an option for many couples in whom "spare" or supernumerary embryos are formed, the decision about what to do with supernumerary embryos is viewed as a clear disadvantage of using PGD [35]. This settlement or disposition issue is complicated and novel approaches are evolving [89] for which there is little empirical evidence to support one option over another. One caveat however, as discussed previously, is that PGD analysis may not be accurate; thus couples may consider the possibility that healthy embryos maybe inadvertently destroyed during the PGD procedure.

Despite the labyrinth of complexity of the moral judgments about embryo status, couples worldwide, experts in the field, and members of the general public, who are grappling with moral evaluations about embryo status related to PGD, are likely to agree that PGD is more morally acceptable than the standard clinical option of prenatal diagnosis with subsequent termination of pregnancy $[36,40,46,77,90,91]$. Some couples formulate an alternative configuration of moral judgment and grant embryos with severe genetic abnormalities a different moral status than healthy embryos [42]. Other couples openly acknowledge that they have chosen not to undergo PGD because it involves the destruction of embryos [44]. 
How couples determine and ultimately judge the moral status of the embryo and its related consequences has immediate implications for their decision surrounding PGD use.

3.3.2. Technological imperative-Couples contemplating PGD formulate moral judgments over the use of advanced technologies for the timeless, naturally-occurring phenomenon of reproduction and genetic selection. Determining whether or not it is morally acceptable to use available technology to examine genetic material in vitro when conceiving a child addresses the technological imperative [see 92]. According to focus groups throughout the United States and couples at high risk of transmitting a genetic disorder, views range from thinking that manipulating embryos through technology "is unnatural or playing God" to believing that there is a moral obligation to improve the human condition through available technology [35,77]. Couples at high risk for transmitting a genetic disorder and who are eligible for PGD have also indicated to their healthcare professionals that choosing not to use PGD is guilt-engendering as they fear that their future child might be disadvantaged if PGD technology is available but not used [79].

3.3.3. Disease and disability prevention-A formidable challenge for couples contemplating PGD is to confront their underlying moral judgments about disease and disability prevention $[93,94]$. Whether or not PGD affects attitudes about disease and disability prevention is widely debated in the literature. Some couples, especially those at high risk for transmitting a genetic disorder, reported that they consider PGD but decline to use it because of the message their decision would imply - that children with a genetic disorder are not valuable or that their affected children are somehow less valuable than "normal" children [44]. Support for this position has been found among others [95] including Freeman [87] who suggested that PGD can cause increased injustice, stigmatization, and discrimination against people with disabilities. There is also concern about the increasing use of PGD for genetically predispositioned adult-onset cancers with a lower penetrance such as breast, ovarian, and colon cancers. Krahn [96] contends that this use of PGD could promote further stigmatization and discrimination of people with genetic disorders or their parents and may ultimately "entrench a culture of prevention and perfectionism and promote a culture of intolerance". Although the concern that PGD may promote stigma, intolerance, and discrimination is found in the literature, opposing views do exist [97-98] and this is also apparent in the increasing numbers of couples who decide to use PGD even with consideration of these moral implications.

3.3.4. Social significance-The importance of the role of PGD in shaping society is widely discussed in the literature and of concern to couples [43-44]. For example, concerns about the eugenic potential of PGD represented the major argument against its development in an international survey of 17 PGD centers [99] and among focus groups representing a broad background of individuals in the United States [77]. However, with steady growth in PGD centers and increasing use worldwide, there appears to be an alternative moral judgment affecting couple's decision making. Suter [100] referred to the term "neoeugenics" to describe couples who exercise their individual reproductive and genetic rights by using PGD in contrast to a broader social eugenic perspective, where state coercion determines whether or not couples can have offspring with or without certain genetic characteristics.

3.3.5. Application-The specific application of PGD plays a role in couples' decision making. In a cogent example from research completed in Germany, a survey of couples at high risk for transferring a genetic disorder, couples undergoing IVF, and a representative sample of the German population, 76\% of respondents indicated acceptance for PGD when it would be used to detect a genetic disease in which a child would likely die during the first year of age [45]. In contrast, in another similar sample of individuals, only $8 \%$ of the 
respondents indicated acceptance for PGD when it would be used for non-medical reasons [101]. The application of PGD for non-medical use (such as determining gender) is often a divisive point among patients, clinicians, and professional groups where strong and varied opinions abound on whether or not PGD should be used [95,102-112]. The relationship between PGD application and its acceptance has been reported among high risk couples' from Saudi Arabia [46], members of the general public in the United States [77], and staff working or linked to a center offering PGD in England [111]. The evidence supports a relationship between couples' decision making surrounding PGD and their determination of the appropriateness of their application for using PGD. Determining precisely how this affects couples' decision making and to what extent, is yet to be uncovered.

\section{Discussion and conclusions}

\subsection{Discussion}

The ethos of couples' decision making surrounding PGD use or disuse stems from three interrelated and dynamic dimensions: cognitive appraisals, emotional responses, and moral judgments. Couples are challenged to think critically about uncertain and probabilistic information regarding the PGD procedure and health risks, grapple with positive and negative emotions, and incorporate personal and societal moral views into their decision making processes. Ultimately, couples must decide what they believe is in the best interest of their family and their future well-being. The conceptual framework, derived from published literature, supports the growing evidence that PGD decisions are complex, they challenge the couple with an array of probabilistic options with little certainty, they arouse pleasant and unpleasant emotions about what the future may hold and they force couples to grapple with their personal moral positions.

\subsection{Theoretical and research implications}

The conceptual framework presented here adds to theoretical knowledge in decision making in several areas. In classical decision theory, researchers typically investigate how individuals should make decisions to maximize positive outcomes [113-114]. The prescriptive process found in classical decision theory posits that the decision maker should gather information, evaluate alternatives, and then determine which option from among the choices maximizes the greatest expected value [113-115]. Classical decision theory is often used to examine rational thinking and our findings demonstrate a relationship to the cognitive aspects of classical theory. Clearly, decisions about PGD involve cognitive appraisals where information processing, perceptions of risk, and evaluating options (i.e. using or foregoing PGD) were reported. We were able to identify what information PGD decision makers may think about but a large gap remains in understanding how the information is actually processed cognitively and how values are applied to each option.

Our findings also support behavioral decision theory where researchers work towards describing and understanding how decisions are made by individuals in an imperfect world [116-118]. In seminal behavioral decision theory research completed by Simon [119-120], the human capacity for a completely rational decision making process was challenged. Our findings pertaining to emotional responses and moral judgments support this aspect of behavioral decision theory. What we were unable to report, however, were specific elements within behavioral decision theory that couples use when contemplating PGD use. For example, Simon demonstrated limits to an individual's decision making processes and coined this process "bounded rationality" [119-121].

Other theoretical work in behavioral decision theory has demonstrated the use of heuristics or cognitive shortcuts that allow decision makers to control the task of information 
processing [122-124]. We provided little knowledge about what are the processing limitations, if any, among couples considering PGD. Furthermore, our review did not shed light upon how particular heuristics might be used by couples. To answer these questions, in-depth research with the couples themselves is needed and we are currently working with couples to understand underlying aspects of decision making processes.

New developments in theoretical constructs in decision theory have espoused the importance of emotional responses in decision making [125-127]. Findings in neuroscience research has recently suggested that emotions are not only the basis for thinking, but that emotions play an integral part in good judgment and rational thought $[82,128]$ thereby providing "hard" evidence for theoretical conceptualizations that link emotions to decision making. The conceptual framework delineated here adds to this existing literature yet extends present knowledge in the field by incorporating a third significant dimension - moral judgments into the decision making process.

Although this review provides an initial synthesis of empirical studies and key documents, the conceptual framework of couples' decision making processes is limited by what has been empirically studied and subsequently published in English. Yet the framework makes a significant contribution by conceptualizing three distinct dimensions that influence couples' decision making surrounding PGD use. Providing a conceptual framework is important since there was minimal explicit evidence about theory or conceptualizations found among the sixteen empirical studies that guided this review. Focused research is needed to examine the precision of the conceptual framework described here and to further identify and refine the dimensions. Moreover, what remains unknown and yet ripe for research is the impact and relationships between the dimensions of the couples' decision making processes in PGD. For example, in what contexts, if any, does the dimension of cognitive appraisals have precedence over the emotional responses dimension or the moral judgments dimension? Additionally, because the review included a broad range of genetic disorders and was limited to publications in English, it is possible that there are other dimensions and subcategories that are specific to other cultures and contexts that have not been described. Since PGD use is expanding, future research that addresses a variety of cultural and contextual areas will provide much needed insight.

Couples confronting PGD are facing evolving reproductive and genetic testing and technology that stretches across cognitive, emotional and moral lines. Yet little is known about how this decision is made interpersonally. Research that provides understanding about how couples resolve divergent aspects of the cognitive, emotional and moral dimensions would be helpful in not only understanding the PGD decision making process but understanding decision making in other emerging areas where familial genetic linkages come into play.

\subsection{Practice implications}

The conceptual framework can assist healthcare professionals in the clinical setting by facilitating couples' decision making surrounding PGD use. Incorporating focused questions from each of the dimensions into counseling sessions would be beneficial. Furthermore, because the framework is built upon understanding both clinical options for PGD use couples who accept PGD and those who decline PGD - the framework can be used as a visual tool to prompt clinicians about important dimensions of couple's decision making when they are contemplating PGD use. This may facilitate meaningful discussion between clinicians and couples as they move through the decision making process.

Understanding couples' decision making surrounding PGD use from a conceptual perspective is an important step in improving the quality of care and guiding future research. 
Our initial conceptualization, derived from current literature, can guide clinical discussion and direct the science of decision making in PGD - a highly controversial, complex, and rapidly evolving technology for which there is currently no clear or optimal imperative.

\section{Acknowledgments}

We are grateful for the partial support provided by the National Institutes of Health (NIH), National Institute of Nursing Research (T32 NR07074 \& R03 NR010351). The review and conceptualization presented here are the authors' interpretations and do not necessarily represent the official views of the NIH. We would also like to acknowledge and thank the attendees of the 2008 Society for Judgment and Decision Making Conference, the Council for the Advancement of Nursing Science Meeting in 2008, and the $9^{\text {th }}$ International Meeting of the Preimplantation Genetic Diagnosis International Society where early drafts of this paper were presented. We sincerely appreciate the assistance of Mark Mershon for his expertise with the figure.

\section{References}

1. Handyside AH, Kontogianni EH, Hardy K, Winston RM. Pregnancies from biopsied human preimplantation embryos sexed by Y-specific DNA amplification. Nature 1990;344:768-70. [PubMed: 2330030]

2. Verlinsky Y, Ginsberg N, Lifchez A, Valle J, Moise J, Strom CM. Analysis of the first polar body: preconception genetic diagnosis. Hum Reprod 1990;5:826-9. [PubMed: 2266156]

3. International Working Group on Preimplantation Genetics. Preimplantation genetic diagnosis: experience of 3000 clinical cycles. Reprod Biomed Online 2001;3:49-53.

4. Verlinsky Y, Rechitsky S, Sharapova T, Morris R, Taranissi M, Kuliev A. Preimplantation HLA testing. JAMA 2004;291:2079-85. [PubMed: 15126435]

5. Goossens V, Harton G, Moutou C, Scriven PN, Traeger-Synodinos J, Sermon K, Harper JC. ESHRE PGD Consortium data collection VIII: cycles from January to December 2005 with pregnancy follow-up to October 2006. Hum Reprod 2008;23:2629-45. [PubMed: 18641400]

6. Handyside AH, Lesko JG, Tarin JJ, Winston RM, Hughes MR. Birth of a normal girl after in vitro fertilization and preimplantation diagnostic testing for cystic fibrosis. N Engl J Med 1992;327:9059. [PubMed: 1381054]

7. Genesis Genetics Institute. PGD testing for hundreds of genetic disorders. [accessed 20/08/2009]. http://www.genesisgenetics.org

8. Reproductive Genetics Institute. What single gene disorders can be tested?. [accessed 20/08/2009]. http://www.reproductivegenetics.com

9. Verlinsky Y, Rechitsky S, Schoolcraft W, Strom C, Kuliev A. Preimplantation diagnosis for Fanconi anemia combined with HLA matching. JAMA 2001;285:3130-3. [PubMed: 11427142]

10. Sermon K. Current concepts in preimplantation genetic diagnosis (PGD): a molecular biologist's view. Hum Reprod Update 2002;8:11-20. [PubMed: 11866237]

11. Verlinsky Y, Cohen J, Munne S, Gianaroli L, Simpson JL, Ferraretti AP, Kuliev A. Over a decade of experience with preimplantation genetic diagnosis: a multicenter report. Fertil Steril 2004;82:292-4. [PubMed: 15302270]

12. Fiorentino F, Biricik A, Nuccitelli A, De Palma R, Kahraman S, Iacobelli M, Trengia V, Caserta D, Bonu MA, Borini A, Baldi M. Strategies and clinical outcome of 250 cycles of Preimplantation Genetic Diagnosis for single gene disorders. Hum Reprod 2006;21:670-84. [PubMed: 16311287]

13. Renwick P, Ogilvie CM. Preimplantation genetic diagnosis for monogenic diseases: overview and emerging issues. Expert Rev Mol Diagn 2007;7:33-43. [PubMed: 17187482]

14. Sermon KD, Michiels A, Harton G, Moutou C, Repping S, Scriven PN, SenGupta S, TraegerSynodinos J, Vesela K, Viville S, Wilton L, Harper JC. ESHRE PGD Consortium data collection VI: cycles from January to December 2003 with pregnancy follow-up to October 2004. Hum Reprod 2007;22:323-36. [PubMed: 17132677]

15. Harper JC, de Die-Smulders C, Goossens V, Harton G, Moutou C, Repping S, Scriven PN, SenGupta S, Traeger-Synodinos J, Van Rij MC, Viville S, Wilton L, Sermon KD. ESHRE PGD consortium data collection VII: cycles from January to December 2004 with pregnancy follow-up to October 2005. Hum Reprod 2008;23:741-55. [PubMed: 18238908] 
16. Verlinsky Y, Rechitsky S, Verlinsky O, Masciangelo C, Lederer K, Kuliev A. Preimplantation diagnosis for early-onset Alzheimer disease caused by V717L mutation. JAMA 2002;287:101821. [PubMed: 11866650]

17. Rechitsky S, Verlinsky O, Chistokhina A, Sharapova T, Ozen S, Masciangelo C, Lederer K, Kuliev A. Preimplantation genetic diagnosis for cancer predisposition. Reprod Biomed Online 2002;5:148-55. [PubMed: 12419039]

18. Debrock S, Melotte C, Vermeesch J, Spiessens C, Vanneste E, D'Hooghe TM. Preimplantation genetic screening (PGS) for aneuploidy in embryos after in vitro fertilization (IVF) does not improve reproductive outcome in women over 35: A prospective controlled randomized study. Fertil Steril 2007;88:S237.

19. Mastenbroek S, Twisk M, van Echten-Arends J, Sikkema-Raddatz B, Korevaar JC, Verhoeve HR, Vogel NE, Arts EG, de Vries JW, Bossuyt PM, Buys CH, Heineman MJ, Repping S, van der Veen F. In vitro fertilization with preimplantation genetic screening. N Engl J Med 2007;357:9-17. [PubMed: 17611204]

20. Practice Committee of the Society for Assisted Reproductive Technology and the Practice Committee of the American Society for Reproductive Medicine. Preimplantation genetic testing: a Practice Committee opinion. Fertil Steril 2007;88:1497-504. [PubMed: 17945219]

21. Collins FS, Green ED, Guttmacher AE, Guyer MS. A vision for the future of genomics research. Nature 2003;422:835-47. [PubMed: 12695777]

22. President's Council on Bioethics. Reproduction and responsibility: The regulation of new biotechnologies. Washington, DC: President's Council on Bioethics; 2004.

23. European Societies of Human Genetics and Human Reproduction and Embryology. The need for interaction between assisted reproduction technology and genetics. Eur J Hum Genet 2006;14:509-11. [PubMed: 16636691]

24. Woodsong C, Severy LJ. Generation of knowledge for reproductive health technologies: Constraints on social and behavioral research. J Soc Issues 2005;61:193-205.

25. Soini S, Ibarreta D, Anastasiadou V, Aymé S, Braga S, Cornel M, Coviello DA, Evers- Kiebooms G, Geraedts J, Gianaroli L, Harper J, Kosztolanyi G, Lundin K, Rodrigues- Cerezo E, Sermon K, Sequeiros J, Tranebjaerg L, Kaariainen $\mathrm{H}$. The interface between assisted reproductive technologies and genetics: technical, social, ethical and legal issues. Eur J Hum Genet 2006;14:588-645. [PubMed: 16636693]

26. Khoury MJ, Gwinn M, Yoon PW, Dowling N, Moore CA, Bradley L. The continuum of translation research in genomic medicine: how can we accelerate the appropriate integration of human genome discoveries into health care and disease prevention? Genet Med 2007;9:665-74. [PubMed: 18073579]

27. Klitzman R, Appelbaum PS, Chung W, Sauer M. Anticipating issues related to increasing preimplantation genetic diagnosis use: a research agenda. Reprod Biomed Online 2008;17:33-42. [PubMed: 18644221]

28. Preimplantation Genetic Diagnosis International Society (PGDIS). Guidelines for good practice in PGD. Reprod Biomed Online 2004;9:430-4. [PubMed: 15511344]

29. Thornhill AR, deDie-Smulders CE, Geraedts JP, Harper JC, Harton GL, Lavery SA, Moutou C, Robinson MD, Schmutzler AG, Scriven PN, Sermon KD, Wilton L. ESHRE PGD Consortium 'Best practice guidelines for clinical preimplantation genetic diagnosis (PGD) and preimplantation genetic screening (PGS)'. Hum Reprod 2005;20:35-48. [PubMed: 15539444]

30. Patel VL, Kaufman DR, Arocha JF. Emerging paradigms of cognition in medical decision-making. J Biomed Inform 2002;35:52-75. [PubMed: 12415726]

31. Cooper, H. Synthesizing research: a guide for literature reviews. 3. Thousand Oaks, CA: Sage; 1998.

32. Pergament E. Preimplantation diagnosis: A patient perspective. Prenat Diagn 1991;11:493-500. [PubMed: 1766924]

33. Miedzybrodzka Z, Templeton A, Dean J, Haites N, Mollison J, Smith N. Preimplantation diagnosis or chorionic villus biopsy? Women's attitudes and preferences. Hum Reprod 1993;8:2192-6. [PubMed: 8150923] 
34. Palomba ML, Monni G, Lai R, Cau G, Olla G, Cao A. Psychological implications and acceptability of preimplantation diagnosis. Hum Reprod 1994;9:360-2. [PubMed: 8027297]

35. Snowdon C, Green JM. Preimplantation diagnosis and other reproductive options: attitudes of male and female carriers of recessive disorders. Hum Reprod 1997;12:341-50. [PubMed: 9070723]

36. Chamayou S, Guglielmino A, Giambona A, Siciliano S, Di Stefano G, Scibilia G, Humeau C, Maggio A, Di Leo S. Attitude of potential users in Sicily towards preimplantation genetic diagnosis for beta-thalassaemia and aneuploidies. Hum Reprod 1998;13:1936-44. [PubMed: 9740453]

37. Alkuraya FS, Kilani RA. Attitude of Saudi families affected with hemoglobinopathies towards prenatal screening and abortion and the influence of religious ruling (Fatwa). Prenat Diagn 2001;21:448-51. [PubMed: 11438947]

38. Henneman L, Bramsen I, Van Os TA, Reuling IE, Heyerman HG, van der Laag J, van der Ploeg HM, ten Kate LP. Attitudes towards reproductive issues and carrier testing among adult patients and parents of children with cystic fibrosis (CF). Prenat Diagn 2001;21:1-9. [PubMed: 11180232]

39. Hui PW, Lam YH, Chen M, Tang MH, Yeung WS, Ng EH, van der Ploeg HM, ten Kate LP. Attitude of at-risk subjects towards preimplantation genetic diagnosis of alpha- and betathalassaemias in Hong Kong. Prenat Diagn 2002;22:508-11. [PubMed: 12116317]

40. Katz MG, Fitzgerald L, Bankier A, Savulescu J, Cram DS. Issues and concerns of couples presenting for preimplantation genetic diagnosis (PGD). Prenat Diagn 2002;22:1117-22. [PubMed: 12454970]

41. Lavery SA, Aurell R, Turner C, Castello C, Veiga A, Barri PN, Winston RM. Preimplantation genetic diagnosis: patients' experiences and attitudes. Hum Reprod 2002;17:2464-7. [PubMed: 12202442]

42. Fernández DO, De Vincentiis S, Chillik CF, Brugo-Olmedo SP. Patients' opinions regarding preimplantation genetic diagnosis in a Latin American fertility clinic. Fertil Steril 2004;81:463-4. [PubMed: 14967393]

43. Roberts C, Franklin S. Experiencing new forms of genetic choice: Findings from an ethnographic study of preimplantation genetic diagnosis. Hum Fertil 2004;7:285-93.

44. Kalfoglou AL, Scott J, Hudson K. PGD patients' and providers' attitudes to the use and regulation of preimplantation genetic diagnosis. Repro Biomed Online 2005;11:486-96.

45. Krones T, Schluter E, Manolopoulos K, Bock K, Tinneberg HR, Koch MC, Lindner M, Hoffmann GF, Mayatepek E, Huels G, Neuwohner E, El Ansari S, Wissner T, Richter G. Public, expert and patients' opinions on preimplantation genetic diagnosis (PGD) in Germany. Reprod Biomed Online 2005;10:116-23. [PubMed: 15705307]

46. Alsulaiman A, Hewison J. Attitudes to prenatal and preimplantation diagnosis in Saudi parents at genetic risk. Prenat Diagn 2006;26:1010-4. [PubMed: 17009348]

47. Menon U, Harper J, Sharma A, Fraser L, Burnell M, ElMasry K, Rodeck C, Jacobs I. Views of BRCA gene mutation carriers on preimplantation genetic diagnosis as a reproductive option for hereditary breast and ovarian cancer. Hum Reprod 2007;22:1573-7. [PubMed: 17428877]

48. Pope, C.; Mays, N.; Popay, J. Synthesizing qualitative and quantitative health evidence: a guide to methods. New York: Open University Press; 2007.

49. Glaser, BG. Theoretical sensitivity: advances in the methodology of grounded theory. Mill Valley, CA: Sociology Press; 1978.

50. Glaser, BG.; Strauss, AL. The discovery of grounded theory. Chicago, IL: Aldine; 1967.

51. Hempel, C. Philosophy of natural science. Upper Saddle River, NJ: Prentice-Hall; 1966.

52. Pasch, LA.; Christensen, A. Couples facing fertility problems. In: Schmaling, KB.; Sher, TG., editors. The psychology of couples and illness: theory, research, \& practice. Washington, DC: American Psychological Association; 2000. p. 241-67.

53. Edwards A, Elwyn G, Covey J, Matthews E, Pill R. Presenting risk information--A review of the effects of "framing" and other manipulations on patient outcomes. J Health Commun 2001;6:6182. [PubMed: 11317424]

54. Liebaers I, Sermon K, Staessen C, Joris H, Lissens W, Van Assche E, Nagy P, Bonduelle M, Vandervorst M, Devroey P, Van Steirteghem A. Clinical experience with preimplantation genetic 
diagnosis and intracytoplasmic sperm injection. Hum Reprod 1998;13:186-95. [PubMed: 9663783]

55. Min JK, Breheny SA, MacLachlan V, Healy DL. What is the most relevant standard of success in assisted reproduction? The singleton, term gestation, live birth rate per cycle initiated: the BESST endpoint for assisted reproduction. Hum Reprod 2004;19:3-7. [PubMed: 14688149]

56. Centers for Disease Control and Prevention. 2006 assisted reproductive technology success rates: national summary and fertility clinic reports. Atlanta, GA: U.S. Department of Health and Human Services Centers for Disease Control and Prevention; 2008.

57. Grace J, El-Toukhy T, Scriven P, Ogilvie C, Pickering S, Lashwood A, Flinter F, Khalaf Y, Braude $\mathrm{P}$. Three hundred and thirty cycles of preimplantation genetic diagnosis for serious genetic disease: clinical considerations affecting outcome. BJOG 2006;113:1393-401. [PubMed: 17176278]

58. Lewis CM, Pinêl T, Whittaker JC, Handyside AH. Controlling misdiagnosis errors in preimplantation genetic diagnosis: a comprehensive model encompassing extrinsic and intrinsic sources of error. Hum Reprod 2001;16:43-50. [PubMed: 11139534]

59. Johnson DS, Rabinowitz M, Cinnioglu C, Keller J, Banjevic M, Singer J, Baner J, Sheena J, Behr B. Novel technology for simultaneous reliable measurement of multiple alleles and copy number across 24 chromosomes in single human blastomeres. Fertil Steril 2008;89:S5.

60. Reddy UM, Wapner RJ, Rebar RW, Tasca RJ. Infertility, assisted reproductive technology, and adverse pregnancy outcomes: Executive summary of a National Institute of Child Health and Human Development workshop. Obstet Gynecol 2007;109:967-77. [PubMed: 17400861]

61. Nekkebroeck J, Bonduelle M, Desmyttere S, Van den Broeck W, Ponjaert-Kristoffersen I. Mental and psychomotor development of 2-year-old children born after preimplantation genetic diagnosis/ screening. Hum Reprod 2008;23:1560-6. [PubMed: 18285321]

62. Tur-Kaspa I, Horwitz A, Ginsberg N, Cieslak J, Rechitsky S, Verlinsky Y. Clinical outcome of PGD. Fertil Steril 2005;84:S99.

63. Hansen M, Kurinczuk JJ, Bower C, Webb S. The risk of major birth defects after intracytoplasmic sperm injection and in vitro fertilization. N Engl J Med 2002;346:725-30. [PubMed: 11882727]

64. Gosden R, Trasler J, Lucifero D, Faddy M. Rare congenital disorders, imprinted genes, and assisted reproductive technology. Lancet 2003;361:1975-7. [PubMed: 12801753]

65. DeBaun MR, Niemitz EL, Feinberg AP. Association of in vitro fertilization with BeckwithWiedemann syndrome and epigenetic alterations of LIT1 and H19. Am J Hum Genet 2003;72:156-60. [PubMed: 12439823]

66. Inhorn MC. Global infertility and the globalization of new reproductive technologies: illustrations from Egypt. Soc Sci Med 2003;56:1837-51. [PubMed: 12650724]

67. Hudson KL. Preimplantation genetic diagnosis: public policy and public attitudes. Fertil Steril 2006;85:1638-45. [PubMed: 16759921]

68. Jain T. Socioeconomic and racial disparities among infertility patients seeking care. Fertil Steril 2006;85:876-81. [PubMed: 16580368]

69. Nachtigall RD. International disparities in access to infertility services. Fertil Steril 2006;85:871-5. [PubMed: 16580367]

70. Thaele M, Uszkoreit M. Legislature's impact on the outcome of infertility treatments - The German political contradiction. Pharm Policy \& Law 2007;9:221-7.

71. Galpern, E. Assisted reproductive technologies: overview and perspective using a reproductive justice framework. Oakland, CA: Center for Genetics and Society; 2007 [accessed 14/11/2008]. http://geneticsandsociety.org/downloads/ART.pdf

72. American Society for Reproductive Medicine. Q6: Is in vitro fertilization expensive?. Frequently asked questions about infertility. [accessed 31/03/2009]. http://www.asrm.org/Patients/faqs.html\#Q6

73. van Balen F, Verdurmen J, Ketting E. Choices and motivations of infertile couples. Patient Educ Couns 1997;31:19-27. [PubMed: 9197799]

74. Katz P, Nachtigall R, Showstack J. The economic impact of the assisted reproductive technologies. Nat Cell Biol 2002;4:S29-S32. [PubMed: 12479612]

75. Jain T, Harlow BL, Hornstein MD. Insurance coverage and outcomes of in vitro fertilization. N Engl J Med 2002;347:661-6. [PubMed: 12200554] 
76. Henne MB, Bundorf MK. Insurance mandates and trends in infertility treatments. Fertil Steril 2008;89:66-73. [PubMed: 17482603]

77. Kalfoglou AL, Doksum T, Bernhardt B, Geller G, LeRoy L, Mathews DJ, Evans JH, Doukas DJ, Reame N, Scott J, Hudson K. Opinions about new reproductive genetic technologies: hopes and fears for our genetic future. Fertil Steril 2005;83:1612-21. [PubMed: 15950627]

78. Inhorn MC, Fakih MH. Arab Americans, African Americans, and infertility: barriers to reproduction and medical care. Fertil Steril 2006;85:844-52. [PubMed: 16580363]

79. Zeiler K. Reproductive autonomous choice--a cherished illusion? Reproductive autonomy examined in the context of preimplantation genetic diagnosis. Med Health Care Philos 2004;7:175-83. [PubMed: 15379192]

80. Gurmankin AD, Ubel PA, Banger E, McGee G. Aspiring parents, genotypes and phenotypes: The unexamined myth of the perfect baby. Albany Law Rev 2005;68:1097-111. [PubMed: 16094768]

81. Hershberger PE. Pregnant, donor oocyte recipient women describe their lived experience of establishing the "family lexicon". J Obstet Gynecol Neonatal Nurs 2007;36:161-7.

82. Sanfey AG. Decision neuroscience: New directions in studies of judgment and decision making. Curr Dir Psychol Sci 2007;16:151-5.

83. ESHRE Task Force on Ethics and Law. I. The moral status of the pre-implantation embryo. Hum Reprod 2001;16:1046-8. [PubMed: 11464802]

84. Roberts JC. Customizing conception: A survey of preimplantation genetic diagnosis and the resulting social, ethical, and legal dilemmas. Duke Law Technol Rev. 2002 July 23;

85. Krones T, Richter G. Preimplantation genetic diagnosis (PGD): European perspectives and the German situation. J Med Philos 2004;29:623-40. [PubMed: 15545119]

86. de Melo-Martin I, Rosenwaks Z, Fins JJ. New methods for deriving embryonic stem cell lines: are the ethical problems solved? Fertil Steril 2006;86:1330-2. [PubMed: 17011558]

87. Freeman JS. Arguing along the slippery slope of human embryo research. J Med Philos 1996;21:61-81. [PubMed: 8740884]

88. Lockwood M. The moral status of the human embryo: implications for IVF. Reprod Biomed Online 2005;10 (Suppl 1):17-20. [PubMed: 15820001]

89. Pickering SJ, Braude PR, Patel M, Burns CJ, Trussler J, Bolton V, Minger S. Preimplantation genetic diagnosis as a novel source of embryos for stem cell research. Reprod Biomed Online 2003;7:353-64. [PubMed: 14653899]

90. Cameron C, Williamson R. Is there an ethical difference between preimplantation genetic diagnosis and abortion? J Med Ethics 2003;29:90-2. [PubMed: 12672888]

91. Robertson JA. Extending preimplantation genetic diagnosis: the ethical debate. Ethical issues in new uses of preimplantation genetic diagnosis. Hum Reprod 2003;18:465-71. [PubMed: 12615807]

92. Kass LR. The wisdom of repugnance: why we should ban the cloning of humans. New Repub 1997;216:17-26. [PubMed: 11654974]

93. Gillam L. Prenatal diagnosis and discrimination against the disabled. J Med Ethics 1999;25:16371. [PubMed: 10226923]

94. McMahan J. The morality of screening for disability. Reprod Biomed Online 2005;10:129-32. [PubMed: 15820024]

95. Vergeer MM, van Balen F, Ketting E. Preimplantation genetic diagnosis as an alternative to amniocentesis and chorionic villus sampling: psychosocial and ethical aspects. Patient Educ Couns 1998;35:5-13. [PubMed: 9832892]

96. Krahn T. Where are we going with preimplantation genetic diagnosis? CMAJ 2007;176:1445-6. [PubMed: 17485698]

97. Savulescu J. Procreative beneficence: Why we should select the best children. Bioethics 2001;15:413-26. [PubMed: 12058767]

98. Savulescu J. In defence of Procreative Beneficence. J Med Ethics 2007;33:284-8. [PubMed: 17470506] 
99. Viville S, Pergament D. Results of a survey of the legal status and attitudes towards preimplantation genetic diagnosis conducted in 13 different countries. Prenat Diagn 1998;18:1374-80. [PubMed: 9949437]

100. Suter SM. A brave new world of designer babies? Berkeley Technol Law J 2007;22:897-969.

101. Meister U, Finck C, Stöbel-Richter Y, Schmutzer G, Brähler E. Knowledge and attitudes towards preimplantation genetic diagnosis in Germany. Hum Reprod 2005;20:231-8. [PubMed: 15471929]

102. Savulescu J. Sex selection--the case for. Med J Aust 1999;171:373-5. [PubMed: 10590728]

103. Ethics Committee of the American Society for Reproductive Medicine. Preconception gender selection for nonmedical reasons. Fertil Steril 2001;75:861-4. [PubMed: 11334894]

104. Malpani A. PGD and sex selection. Hum Reprod 2002;17:517. [PubMed: 11821306]

105. Pennings G. Personal desires of patients and social obligations of geneticists: applying preimplantation genetic diagnosis for non-medical sex selection. Prenat Diagn 2002;22:1123-9. [PubMed: 12454971]

106. Steinbock B. Sex selection: Not obviously wrong. Hastings Cent Rep 2002;32:23-8. [PubMed: 11917705]

107. Stern JE, Cramer CP, Green RM, Garrod A, DeVries KO. Determining access to assisted reproductive technology: reactions of clinic directors to ethically complex case scenarios. Hum Reprod 2003;18:1343-52. [PubMed: 12773470]

108. Keye WR Jr, Bradshaw KD. A survey of the practices and opinions of the domestic members of the American Society for Reproductive Medicine. Fertil Steril 2004;82:536-42. [PubMed: 15374686]

109. Jain T, Missmer SA, Gupta RS, Hornstein MD. Preimplantation sex selection demand and preferences in an infertility population. Fertil Steril 2005;83:649-58. [PubMed: 15749494]

110. ACOG (American College of Obstetricians and Gynecologists). ACOG Committee opinion no. 360: sex selection. Obstet Gynecol 2007;109:475-8. [PubMed: 17267863]

111. Williams C, Ehrich K, Farsides B, Scott R. Facilitating choice, framing choice: Staff views on widening the scope of preimplantation genetic diagnosis in the UK. Soc Sci Med 2007;65:1094105. [PubMed: 17573171]

112. Human Fertilisation and Embryology Authority. Code of practice. 7. London: Human Fertilisation and Embryology Authority; 2009 [accessed 20/03/2009]. http://cop.hfea.gov.uk/cop/

113. von Neumann, J.; Morgenstern, O. Theory of games and economic behavior. 2. Princeton, NJ: Princeton University Press; 1947.

114. Raiffa, H. Decision analysis: introductory lectures on choices under uncertainty. New York: Random House; 1968.

115. Lau, RR. Models of decision making. In: Sears, DO.; Huddy, L.; Jervis, R., editors. Oxford handbook of political psychology. New York: Oxford University Press; 2003. p. 19-59.

116. Tversky A, Kahneman D. The framing of decisions and the psychology of choice. Science 1981;211:453-8. [PubMed: 7455683]

117. Klein, GA.; Orasanu, J.; Calderwood, R.; Zsambok, CE. Decision making in action: models and methods. Norwood, NJ: Ablex; 1993.

118. Connolly, T.; Arkes, HR.; Hammond, KR. Judgment and decision making: An interdisciplinary reader. 2. New York: Cambridge University Press; 1999.

119. Simon, HA. Administrative behavior. New York: Macmillan; 1947.

120. Simon, HA. Models of man: social and rational. New York: Wiley; 1957.

121. Simon HA. Information processing models of cognition. Annu Rev Psychol 1979;30:363-96. [PubMed: 18331186]

122. Kahneman D, Tversky A. Subjective probability: a judgment of representativeness. Cogn Psychol 1972;3:430-54.

123. Kahneman D, Tversky A. On the psychology of prediction. Psychol Rev 1973;80:237-51.

124. Tversky A, Kahneman D. Judgment under uncertainty: heuristics and biases. Science 1974;185:1124-31. [PubMed: 17835457] 
125. Loewenstein G. Out of control: visceral influences on behavior. Organ Behav Hum Decis Process 1996;65:272-92.

126. Zajonc, RB. Emotions. In: Gilbert, DT.; Fiske, ST.; Lindzey, G., editors. The handbook of social psychology. Vol. 1. New York: Academic Press; 1998. p. 591-632.

127. Lerner JS, Keltner D. Beyond valence: toward a model of emotion-specific influences on judgement and choice. Cogn Emot 2000;14:473-93.

128. Bechara A, Damasio H, Tranel D, Damasio AR. Deciding advantageously before knowing the advantageous strategy. Science 1997;275:1293-5. [PubMed: 9036851] 


\section{Dimensions of Couples' Decision Making in PGD}

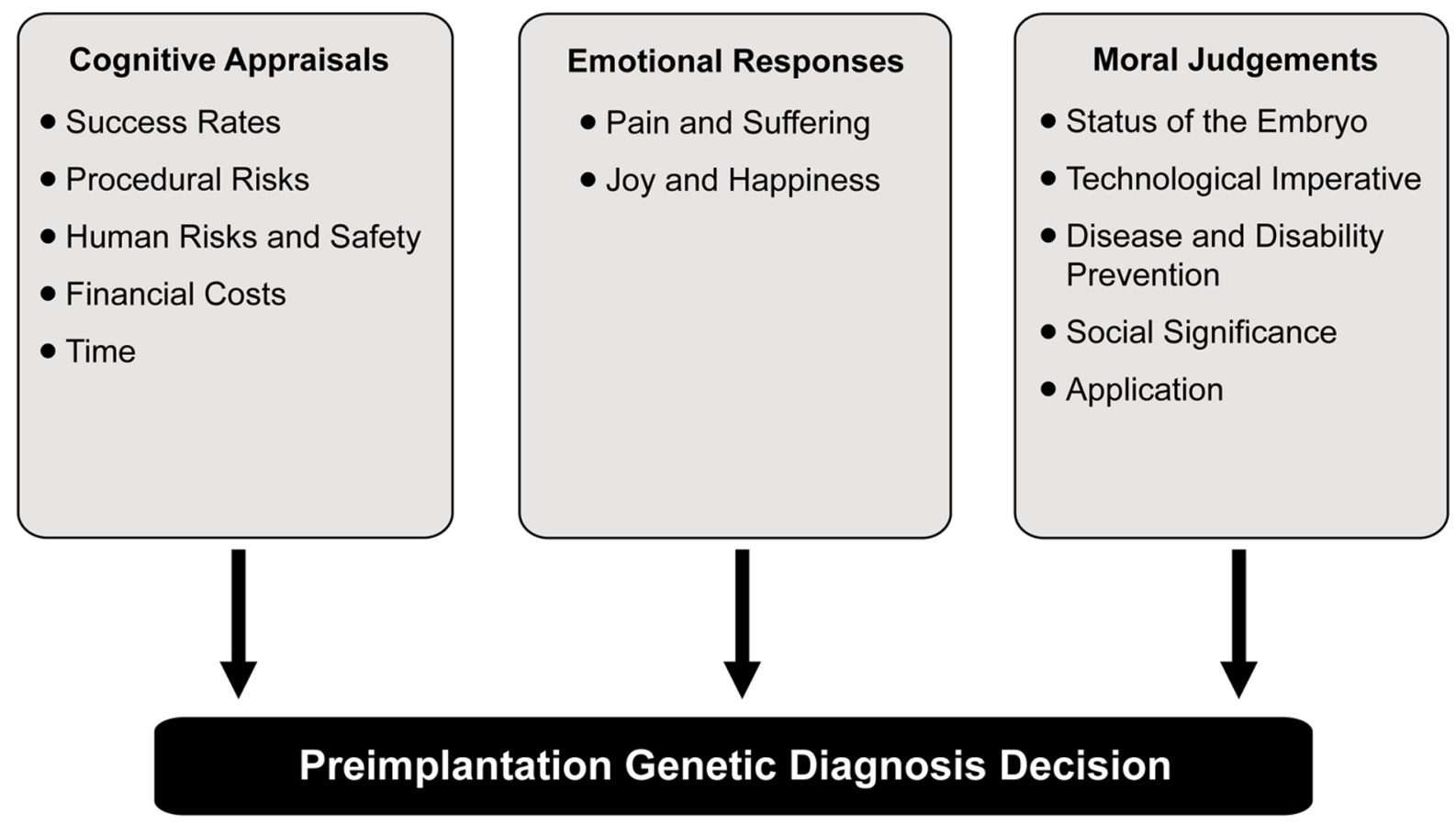

Figure 1.

Framework for the Emerging Dimensions of Couples' Decision Making PGD. 
Table 1

Empirical Studies Examining PGD from the Perspective of Couples or Individual Partners at High Genetic Risk

\begin{tabular}{|c|c|c|c|}
\hline Publication & Country & Sample & Aim \\
\hline Pergament, 1991 [32] & United States & 58 American women at high genetic risk & $\begin{array}{l}\text { Describe impressions and attitudes } \\
\text { towards PGD by potential women } \\
\text { users at high genetic risk for } \\
\text { transmitting a genetic disorder. }\end{array}$ \\
\hline $\begin{array}{l}\text { Miedzybrodzka et al., } \\
1993 \text { [33] }\end{array}$ & United Kingdom & $\begin{array}{l}\text { Surveyed: (A) } 46 \text { women who had genetic } \\
\text { counseling and were at risk for transmitting single } \\
\text { gene disorders, (B) } 18 \text { women who had undergone } \\
\text { CVS for a single gene disorder, (C) } 158 \text { women } \\
\text { who had undergone CVS for other reasons, (D) } \\
200 \text { women who had recently delivered a normal } \\
\text { baby, and (E) } 50 \text { women who used IVF } \\
\text { unsuccessfully and were awaiting another IVF } \\
\text { treatment cycle. }\end{array}$ & $\begin{array}{l}\text { Assess women's attitudes and } \\
\text { preferences to PGD and CVS for } \\
\text { genetic disorders. }\end{array}$ \\
\hline Palomba et al., 1994 [34] & Italy & $\begin{array}{l}180 \text { pregnant Italian women at high risk for } \beta- \\
\text { thalassaemia. The participants were recruited } \\
\text { several days before undergoing CVS. }\end{array}$ & $\begin{array}{l}\text { Ascertain the degree of } \\
\text { acceptability of PGD in women at } \\
\text { high risk for transmitting } \beta \text { - } \\
\text { thalassaemia. }\end{array}$ \\
\hline $\begin{array}{l}\text { Snowdon \& Green, } 1997 \\
\text { [35] }\end{array}$ & United Kingdom & 245 carriers of recessive disorders. & $\begin{array}{l}\text { Describe the attitudes of couples, } \\
\text { known to carry a recessive disorder, } \\
\text { towards PGD use. }\end{array}$ \\
\hline $\begin{array}{l}\text { Chamayou et al., } 1998 \\
\text { [36] }\end{array}$ & Italy \& France & $\begin{array}{l}\text { Surveyed four different population types: (A) } 54 \\
\text { high risk couples for } \beta \text {-thalassaemia presenting for } \\
\text { their initial PND, (B) } 51 \text { similar couples presenting } \\
\text { for their second or further PND without previous } \\
\text { experience of therapeutic pregnancy termination, } \\
\text { (C) } 50 \text { similar couples presenting for their second } \\
\text { or further PND with previous experience of } \\
\text { therapeutic pregnancy termination for a } \beta \text { - } \\
\text { thalassaemia affected fetus, and (D) } 74 \text { infertile } \\
\text { couples undergoing routine IVF. }\end{array}$ & $\begin{array}{l}\text { Describe the willingness of four } \\
\text { different population types to } \\
\text { undergo PGD for } \beta \text {-thalassaemia as } \\
\text { an alternative to PND and the } \\
\text { willingness of infertile couples to } \\
\text { undergo PGD for aneuploidies. }\end{array}$ \\
\hline $\begin{array}{l}\text { Alkuraya \& Kilani, } 2001 \\
\text { [37] }\end{array}$ & Saudi Arabia & $\begin{array}{l}32 \text { Saudi parents attending an outpatient clinic with } \\
\text { one or more children affected by } \\
\text { hemoglobinopathies. }\end{array}$ & $\begin{array}{l}\text { Describe the attitudes of high risk } \\
\text { Saudi parents toward PND and } \\
\text { PGD and to examine the effect of } \\
\text { an educational intervention about } \\
\text { religious ruling on attitudes. }\end{array}$ \\
\hline $\begin{array}{l}\text { Henneman } \text { et al., } 2001 \\
{[38]}\end{array}$ & The Netherlands & $\begin{array}{l}287 \text { adult patients with cystic fibrosis and } 288 \\
\text { parents of a child with cystic fibrosis. }\end{array}$ & $\begin{array}{l}\text { Examine attitudes towards } \\
\text { reproductive issues and carrier } \\
\text { screening and parents' reproductive } \\
\text { behaviors and choices regarding } \\
\text { adoption, artificial insemination, } \\
\text { and PGD. }\end{array}$ \\
\hline Hui et al., 2002 [39] & China & $\begin{array}{l}141 \text { Asian women at high risk for transmitting } a \text { - } \\
\text { or } \beta \text {-thalassaemia to a future child. }\end{array}$ & $\begin{array}{l}\text { Assess whether PGD was an } \\
\text { acceptable alternative to PND in } \\
\text { Asian couples at high risk of giving } \\
\text { birth to a child with } a \text { - or } \beta \text { - } \\
\text { thalassaemia. }\end{array}$ \\
\hline Katz et al., 2002 [40] & Australia & $\begin{array}{l}\text { Three groups of couples consisting of: (A) } 41 \\
\text { subjects ( } 20 \text { couples + } 1 \text { mother) presenting for } \\
\text { PGD of single gene disorders, (B) } 48 \text { subjects ( } 24 \\
\text { couples) undertaking PGD for aneuploidy } \\
\text { screening, and (C) control group of } 32 \text { subjects ( } 16 \\
\text { couples) that were about to begin their first IVF } \\
\text { treatment cycle. }\end{array}$ & $\begin{array}{l}\text { Describe social and moral concerns } \\
\text { and attitudes of couples, who have } \\
\text { experience with genetic disease, } \\
\text { chromosomal abnormalities, or } \\
\text { infertility, toward PGD use. }\end{array}$ \\
\hline Lavery et al., 2002 [41] & $\begin{array}{l}\text { United Kingdom } \\
\& \text { Spain }\end{array}$ & $\begin{array}{l}36 \text { couples who had undergone PGD from centers } \\
\text { in London, England and Barcelona, Spain. }\end{array}$ & $\begin{array}{l}\text { Describe the experiences and } \\
\text { attitudes of couples who have } \\
\text { undergone PGD and detail their } \\
\text { perceived advantages and } \\
\text { disadvantages of using PGD and } \\
\text { PND. }\end{array}$ \\
\hline
\end{tabular}




\begin{tabular}{|c|c|c|c|}
\hline Publication & Country & Sample & Aim \\
\hline $\begin{array}{l}\text { Fernández et al., } 2004 \\
\text { [42] }\end{array}$ & Argentina & $\begin{array}{l}\text { 130 Latin American subjects ( } 83 \% \text { women and } \\
17 \% \text { men) comprised of: (A) } 58 \% \text { with infertility } \\
\text { problems, (B) } 26 \% \text { presenting with a history of } \\
\text { conception, (C) } 16 \% \text { having no children. Of the } \\
\text { sample, about } 21 \% \text { had a history of recurrent } \\
\text { miscarriages and } 17 \% \text { had undergone a pregnancy } \\
\text { termination. }\end{array}$ & $\begin{array}{l}\text { Explore the acceptance of PGD } \\
\text { versus PND, the moral status of the } \\
\text { embryo, acceptance of novel } \\
\text { applications of PGD, and } \\
\text { considerations on the disposition of } \\
\text { abnormal embryos among Latin } \\
\text { Americans. }\end{array}$ \\
\hline $\begin{array}{l}\text { Roberts \& Franklin, } 2004 \\
\text { [43] }\end{array}$ & United Kingdom & $\begin{array}{l}21 \text { patients undergoing PGD in two clinics in } \\
\text { England. Seven patients had one child with a fatal } \\
\text { genetic disorder and one case had two children } \\
\text { with a fatal genetic disorder. }\end{array}$ & $\begin{array}{l}\text { Describe parent's experiences of } \\
\text { making the decision to undergo } \\
\text { PGD and of making reproductive } \\
\text { choices based on genetic } \\
\text { information. }\end{array}$ \\
\hline Kalfoglou et al., 2005 [44] & United States & $\begin{array}{l}13 \text { individuals at high risk for transmitting a single } \\
\text { gene disorder to their future children ( } 10 \text { subjects } \\
\text { had undergone PGD). Included in the sample were } \\
19 \text { PGD providers (nurses, genetic counselors, } \\
\text { physicians, embryologist, and lab directors). }\end{array}$ & $\begin{array}{l}\text { Describe the experiences and } \\
\text { attitudes of PGD patients and } \\
\text { providers about the use and } \\
\text { regulation of PGD. }\end{array}$ \\
\hline Krones et al., 2005 [45] & Germany & $\begin{array}{l}\text { Survey composed of: (A) } 1017 \text { subjects who were } \\
\text { representative of the general population of } \\
\text { reproductive age individuals, (B) } 879 \text { subjects in } \\
\text { five expert professional groups, (C) } 324 \text { subjects } \\
\text { who are high genetic risk couples, and (D) } 108 \\
\text { cases ( } 54 \text { couples) undergoing IVF. }\end{array}$ & $\begin{array}{l}\text { Assess the attitudes on PGD in the } \\
\text { general population, expert groups, } \\
\text { high genetic risk couples, and } \\
\text { couples undergoing IVF in } \\
\text { Germany. }\end{array}$ \\
\hline $\begin{array}{l}\text { Alsulaiman \& Hewison, } \\
2006 \text { [46] }\end{array}$ & $\begin{array}{l}\text { Saudi Arabia \& } \\
\text { United Kingdom }\end{array}$ & $\begin{array}{l}30 \text { couples offered genetic counseling following } \\
\text { the birth of a child with a single gene or } \\
\text { chromosomal disorder. }\end{array}$ & $\begin{array}{l}\text { Explore the acceptability of PGD in } \\
\text { high genetic risk Saudi couples. }\end{array}$ \\
\hline Menon et al., 2007 [47] & United Kingdom & $\begin{array}{l}52 \text { BRCA gene mutation carriers attending a } \\
\text { Familial Cancer Center in London, England. }\end{array}$ & $\begin{array}{l}\text { Describe the views of BRCA gene } \\
\text { mutation carriers on the use of PGD } \\
\text { for hereditary breast and ovarian } \\
\text { cancers. }\end{array}$ \\
\hline
\end{tabular}

Abbreviation Key: BRCA = Breast and Ovarian Cancer Susceptibility Genes

CVS $=$ Chorionic Villus Sampling

$\mathrm{IVF}=\mathrm{In}$ Vitro Fertilization

PGD $=$ Preimplantation Genetic Diagnosis

$\mathrm{PND}=$ Prenatal Diagnosis 